\title{
PENGARUH PEMBERIAN PUPUK KASCING DAN NPK MUTIARA 16:16:16 TERHADAP PERTUMBUHAN DAN HASIL OKRA (Abelmoschus esculentus (L.) Moenc.) SERTA BAWANG MERAH (Allium ascalonicum L.) DENGAN SISTEM TUMPANG SARI
}

\section{The Effect of Kascing Fertilizer and Mutiara NPK 16:16:16 on Growth and Production of Okra (Abelmoschus esculentus (L.) Moenc.) and Onion (Allium ascalonicum L.) with Intercropping System}

\author{
Wahyu Hidayatullah, T. Rosmawaty dan M. Nur \\ Program Studi Agroteknologi, Fakultas Pertanian Universitas Islam Riau \\ J1. Khaharuddin Nasution No.113 Pekanbaru. 28284 \\ Email: wahyu927@student.uir.ac.id \\ [Diterima: Desember 2019; Disetujui: April 2020]
}

\begin{abstract}
The purpose of this study is to examine the interactions between kascing fertilizers and mutiara NPK 16:16:16 on the growth and production of okra and shallots in the intercropping system. This research used a completely randomized factorial design, consisting of two factors. The first factor was the application of vermicompost (K), consisting of 4 levels, namely $0,750,1500$ and $2250 \mathrm{~g} / \mathrm{plot}$ and the second factor was NPK 16:16: $16(\mathrm{~N})$, consisting of 4 levels, namely $0,15,30$ and $45 \mathrm{~g} / \mathrm{plot}$, so that obtained 16 treatment combinations with 3 replications and 48 experimental units. Each unit consisted of 4 plants per plot and 2 plants are samples, so that the plant had 192 plants for okra plants and 5 plots for shallots and 2 plants was become samples with total plants of 240 . Based on research results indicated that intercropping system on okra plants and shallots resulted smaller plant growth and production compared to monocultures. The interaction of kascing fertilizer and NPK 16:16:16 fertilizer had no significant on all observed parameters. The main effect of the dose of kascing fertilizer was a significance on all observed parameters. The best treatment was significant on a dose of kascing fertilizer of $2250 \mathrm{~g} / \mathrm{plot}$. The main effect of the 16:16:16 NPK dose was significant on all observed parameters. The best treatment was found on NPK 16:16:16 with dose of $45 \mathrm{~g} / \mathrm{plot}$.
\end{abstract}

Keywords: Kascing, Mutiara 16:16:16, Okra, Onion

\begin{abstract}
ABSTRAK
Penelitian ini bertujuan untuk mengetahui pengaruh interaksi antara pupuk kascing dan pupuk NPK 16:16:16 pada pertumbuhan dan produksi okra dan bawang merah pada sistem tumpang sari. Penelitian ini menggunakan Rancangan Acak Lengkap (RAL) Faktorial yang terdiri dari dua faktor. Faktor pertama adalah pemberian Kascing (K) terdiri dari 4 taraf yaitu 0, 750, 1500 dan $2250 \mathrm{~g} / \mathrm{plot}$ dan faktor kedua NPK 16:16:16 (N) yang terdiri dari 4 taraf yaitu $0,15,30$ dan 45 g/plot, sehingga diperoleh 16 kombinasi perlakuan dengan 3 kali ulangan maka ada 48 unit percobaan. Masing-masing unit terdiri dari 4 tanaman per plot dan 2 tanaman dijadikan sampel pengamatan, sehingga keseluruhan tanaman adalah 192 tanaman untuk tanaman okra dan 5 tanaman per plot untuk bawang merah dan 2 tanaman sebagai sampel dengan jumlah keseluruhan tanaman ialah 240. Berdasarkan hasil penelitian mengindikasikan bahwa sistem tanam tumpang sari pada tanaman okra dan bawang merah menghasilkan pertumbuhan dan produksi tanaman yang lebih kecil dibandingkan dengan tanaman yang ditanam secara monokultur. Interaksi pemberian pupuk kascing dan pupuk NPK 16:16:16 tidak nyata terhadap semua parameter pengamatan. Pengaruh utama dosis pupuk kascing nyata terhadap semua parameter pengamatan. Perlakuan terbaik adalah dosis pupuk kascing $2250 \mathrm{~g} / \mathrm{plot}$. Pengaruh utama dosis NPK 16:16:16 nyata terhadap semua parameter pengamatan. Perlakuan terbaik adalah dosis NPK 16:16:16 $45 \mathrm{~g} / \mathrm{plot}$.
\end{abstract}

Kata kunci: Kascing, Mutiara 16:16:16, Okra, Bawang merah 


\section{PENDAHULUAN}

Peningkatan produktivitas lahan yang berada di areal sempit dapat dilakukan dengan menerapkan sistem tanaman ganda, antara lain dengan sistem tumpang sari (intercropping), dimana pada sebidang lahan ditanami lebih dari satu jenis tanaman, misalnya tumpang sari antara okra dengan bawang merah. Penanaman dengan sistem tumpang sari diyakini lebih aman dari pada sistem tanaman tunggal, keseimbangan biologis tanaman terjaga, hasil tanaman beraneka ragam, dan risiko kegagalan panen berkurang (Sasmita, 2014).

Untuk menghindari kegagalan usaha ada upaya yang dianjurkan yaitu dengan menanam secara tumpang sari. Teknologi budidaya tumpang sari salah satu yang dapat diterapkan adalah tanaman okra (Abelmoschus esculentus (L.) Moenc.) dan bawang merah (Allium ascalonicum L.) karena dapat memanfaatkan secara optimal lahan yang tersedia, sehingga pendapatan petani dapat meningkat.

Manfaat bagi tanaman okra salah satunya yaitu aroma dari tanaman bawang merah dapat menjauhkan hama dari tanaman okra, sehingga tanaman okra baik ditanam secara tumpang sari dengan bawang merah. Manfaat bagi bawang merah sebagai naungan agar matahari tidak langsung mengenai tanaman bawang merah.

Salah satu pupuk organik yang sangat baik digunakan untuk budidaya tanaman hortikultura adalah pupuk kascing. Kascing merupakan pupuk yang bahan asalnya berupa kotoran cacing (Lumbricus rubellus). Kascing dihasilkan dari kompos yang diperoleh dari perombakan bahan organik yang dibuat oleh cacing tanah. Kasing adalah campuran kotoran cacing tanah yang dicampur dengan kotoran cacing tanah. Oleh karena itu, kascing adalah pupuk organik yang ramah lingkungan dan memiliki kelebihan unik dibandingkan kompos lainnya (Anonimus, 2009).

Kandungan nutrisi kascing (N, P, K) dapat mencapai dua kali lipat kompos. Kascing juga mengandung pengatur pertumbuhan tanaman dan mikroorganisme tanah. Isi keseluruhan kompos cacing tanah, bahan kimia, dan organisme membuat nutrisi tersedia yang diserap oleh tanaman untuk mengurangi nutrisi kompos cacing tanah dan menambahkan pupuk anorganik. Penggunaan pupuk anorganik penting untuk pertumbuhan dan produksi okra dan bawang merah. Pupuk anorganik larut dengan cepat dan mudah tersedia di tanah, sehingga mudah diserap oleh tanaman. Pasokan pupuk yang mengandung nutrisi makro, $\mathrm{P}$, dan $\mathrm{K}$ yang seimbang dapat mendukung pertumbuhan dan perkembangan tanaman.

Pupuk Npk 16:16:16 Merupakan Salah Satu Pupuk Anorganik Majemuk Yang Mengandung Unsur Hara Makro Dan Mikro. Pupuk Npk Mutiara 16:16:16 Mengandung 3 Unsur Hara Makro Dan 2 Unsur Hara Mikro. Unsur Hara Tersebut Adalah Nitrogen 16\%, Phospat 16\%, Kalium 16\%, Kalsium 6\% Dan Magnesium 0,5\%. Pupuk Ini Bersifat Higroskopis Atau Mudah Larut Sehingga Mudah Diserap Oleh Tanaman Dan Bersifat Netral Atau Tidak Mengasamkan Tanah (Widyaastuti, 2009). Tujuan penelitian ini adalah untuk mengetahui pengaruh secara interaksi dan utama pemberian pupuk kascing dan NPK mutiara 16:16:16 terhadap pertumbuhan dan hasil okra (Abelmoschus esculentus (1.) Moenc.) serta bawang merah (Allium ascalonicum L.) dengan sistem tumpang sari

\section{BAHAN DAN METODE}

Penelitian ini telah dilaksanakan di Kebun Percobaan Fakultas Pertanian Universitas Islam Riau, Jalan Kaharuddin Nasution KM 11, Kelurahan Air Dingin, Kecamatan Bukit Raya, Kota Pekanbaru. Waktu penelitian ini di laksanakan selama tiga bulan yang terhitung mulai dari bulan Juli sampai dengan September 2019.

Bahan penelitian yang di gunakan adalah benih okra varietas Greennie, bibit bawang merah Varietas Bima Brebes, pupuk kascing, pupuk NPK Mutiara 16:16:16, Curacron 500 EC, Dhitane M-45. Sedangkan alat-alat yang digunakan adalah cangkul, parang, pisau stainles, tali rafia, gembor, kamera, meteran, ember, hand sprayer, plat seng dan alat tulis.

Penelitian ini menggunakan rancangan acak lengkap yang terdiri dari dua faktor. Faktor pertama adalah pemberian kompos cacing tanah $(\mathrm{K})$, yang terdiri dari 4 level, dan faktor kedua adalah NPK 16:16:16 $(\mathrm{N})$, yang terdiri dari 4 level. Dengan demikian, ada 48 unit percobaan karena 3 ulangan akan menghasilkan 16 kombinasi pengobatan. Setiap unit terdiri dari 4 tanaman per plot, 2 
tanaman diambil sampelnya, dan seluruh tanaman menjadi 192 tanaman untuk okra dan 5 tanaman per plot bawang merah, dan 2 tanaman diambil sampelnya, sehingga jumlah total tanaman adalah 240 tanaman.

Data pengamatan terakhir dianalisa secara statistik dengan menggunakan analisis sidik ragam (ANOVA). Apabila F hitung yang diperoleh lebih besar dari $\mathrm{F}$ tabel, maka dilanjutkan dengan melakukan uji lanjut Beda Nyata Jujur (BNJ) pada taraf $5 \%$.

\section{Tinggi Tanaman (cm)}

Pengamatan ketinggian tanaman okra dan bawang merah ditanam dalam sistem tumpangsari setelah analisis varians tidak menunjukkan efek nyata pada interaksi antara kompos cacing tanah dan pupuk NPK 16:16:16 Efeknya menunjukkan bahwa itu adalah tinggi tanaman. Pengamatan rata-rata ketinggian okra dan tanaman bawang merah dalam tumpangsari dapat dilihat pada Tabel 1 dan 2.

\section{HASIL DAN PEMBAHASAN}

Tabel 1. Rerata tinggi tanaman okra dengan perlakuan pupuk kascing dan dosis pupuk NPK 16:16:16 secara tumpang sari $(\mathrm{cm})$ pada umur 56 hst.

\begin{tabular}{|c|c|c|c|c|c|}
\hline \multirow{2}{*}{$\begin{array}{l}\text { Pupuk Kascing } \\
\text { (g/plot) }\end{array}$} & \multicolumn{4}{|c|}{ Dosis Pupuk NPK 16:16:16 (g/plot) } & \multirow[t]{2}{*}{ Rerata } \\
\hline & N0 (0) & N1 (15) & $\mathrm{N} 2(30)$ & N3 (45) & \\
\hline K0 (0) & $\overline{71,33}$ & 72,69 & 74,11 & 75,33 & $73,37 \mathrm{~b}$ \\
\hline K1 (750) & 75,41 & 74,86 & 76,45 & 75,05 & $75,44 \mathrm{ab}$ \\
\hline K2 (1500) & 73,36 & 75,55 & 76,50 & 77,86 & $75,82 \mathrm{ab}$ \\
\hline K3 (2250) & 73,89 & 76,97 & 77,94 & 79,47 & $77,07 \mathrm{a}$ \\
\hline Rerata & $73,50 \mathrm{~b}$ & $75,02 \mathrm{ab}$ & $76,25 \mathrm{ab}$ & $76,93 \mathrm{a}$ & \\
\hline
\end{tabular}

Angka-angka pada kolom dan baris yang diikuti huruf kecil yang sama tidak berbeda nyata menurut uji BNJ pada taraf 5\%.

Tabel 2. Rerata tinggi tanaman bawang merah dengan perlakuan pupuk kascing dan dosis pupuk NPK 16:16:16 secara tumpang sari $(\mathrm{cm})$ umur 42 hst.

\begin{tabular}{|c|c|c|c|c|c|}
\hline \multirow{2}{*}{$\begin{array}{c}\text { Pupuk Kascing } \\
\text { (g/plot) }\end{array}$} & \multicolumn{4}{|c|}{ Dosis Pupuk NPK 16:16:16 (g/plot) } & \multirow[t]{2}{*}{ Rerata } \\
\hline & N0 (0) & N1 (15) & $\mathrm{N} 2(30)$ & N3 (45) & \\
\hline K0 (0) & 27,00 & 27,69 & 29,11 & 30,33 & $28,53 \mathrm{~b}$ \\
\hline K1 (750) & 28,41 & 29,20 & 29,78 & 30,05 & $29,36 \mathrm{~b}$ \\
\hline K2 (1500) & 28,36 & 30,55 & 31,50 & 32,19 & $30,65 \mathrm{ab}$ \\
\hline K3 (2250) & 28,89 & 32,31 & 33,28 & 34,47 & $32,24 \mathrm{a}$ \\
\hline Rerata & $28,17 \mathrm{~b}$ & $29,94 \mathrm{ab}$ & $30,92 \mathrm{a}$ & $31,76 \mathrm{a}$ & \\
\hline
\end{tabular}

Angka-angka pada kolom dan baris yang diikuti huruf kecil yang sama tidak berbeda nyata menurut uji BNJ pada taraf 5\%".

Tinggi tanaman okra tumpang sari dengan bawang merah lebih rendah jika dibandingkan dengan tanaman yang ditanam secara monokultur. Tanaman okra hasil tumpang sari menghasilkan tinggi tanaman 79,47 cm, sedangkan tanaman okra yang ditanam secara monokultur menghasilkan tinggi tanaman mencapai $87,33 \mathrm{~cm}$. Hal ini dikarenakan penanaman okra secara tumpang sari memberikan hambatan dalam pemenuhan kebutuhan hara pada okra, sehingga adanya persaingan perebutan unsur hara pada pertumbuhan dan perkembangan tanaman, sehingga menghambat pertumbuhan vegetative tanaman okra sebagai tanaman utama.
Ini konsisten dengan hasil Suresha et al. (2010) Pertumbuhan tanaman budidaya tunggal lebih tinggi daripada tumpangsari. Karena ada persaingan yang baik untuk menerima sinar matahari, nutrisi dan air.

Tinggi tanaman bawang secara tumpang sari lebih rendah jika dibandingkan dengan tinggi tanaman yang ditanam secara monokultur. Pada tanaman monokultur menghasilkan tinggi $43,33 \mathrm{~cm}$, sedangkan bawang tumpang sari $34,47 \mathrm{~cm}$. hal ini disebabkan adanya persaingan air, hara dan penyinaran pada tanaman tumpang sari.

Faktor lain yang mempengaruhi tinggi tanaman adalah penyinaran yang diterima oleh tanaman, semakin baik penyinaran pada tanmaan maka semakin baik proses fotosintesi yang terjadi pada tanaman. Apabila tanaman ternaungi maka tanaman akan berusaha 
mencari sumber cahaya, tetapi proses ini akan berjalan tidak baik bila tanaman juga mengalami kekurangan hara.

Pada Tabel 1 menunjukkan bahwa pengaruh utama perlakuan pupuk kascing memberikan pengaruh yang berbeda nyata terhadap tinggi tanaman okra, dimana perlakuan terbaik dosis pupuk kascing 2250 g/plot (K3) yaitu: 77,07 cm. Diduga pemberian pupuk kascing yang mampu memperbaiki tingkat kesuburan tanah, selain itu pupuk kascing juga mampu menyumbangkan hara makro seperti $\mathrm{N}$ pada tanaman okra, sehingga memacu pertumbuhan vegetatif tanaman okra.

Perlakuan K3 tidak berbeda dengan perlakuan K2 dan K1 disebabkan pada pemberian pupuk kascing walau dalam jumlah yang banyak memiliki peran yang hampir sama dengan pemberian dosis yang relatif sedikit, hal ini kemungkinan $\mathrm{N}$ tersedia dalam tanah berbeda, sehingga memberikan serapan hara yang dilakukan akar tanaman juga berbeda.

Pada Tabel 2 menunjukkan bahwa pengaruh utama pemberian pupuk kascing memberikan pengaruh yang berbeda nyata terhadap tinggi tanaman bawang merah, dimana perlakuan terbaik pada dosis 2250 g/plot (K3) dengan tinggi tanaman $32,24 \mathrm{~cm}$. Dikarenakan pemberian pupuk kascing yang mencapai $2250 \mathrm{~g}$ per plot mampu meningkatkan ketersediaan hara $\mathrm{N}$ di dalam tanah, sehingga menghasilkan tinggi tanaman yang tinggi pada perlakuan K3, walau kandungan hara yang relatif sedikit dibandingkan dengan pupuk kimia, pemberian pupuk kascing yang mencapai $2250 \mathrm{~g}$ per plot diduga mampu meningkatkan ketersediaan hara dalam tanah.

Pada Tabel 1 menunjukkan bahwa pengaruh utama perlakuan NPK 16:16:16 memberikan pengaruh yang berbeda nyata terhadap tinggi tanaman okra, dimana perlakuan terbaik pada dosis NPK 16:16:16 43 g/plot (N3) dengan tinggi tanaman 76,93 cm. Hal ini disebabkan kandunga hara makro yang diberikan melalui pemupukan NPK 16:16:16 mampu diserap dengan baik oleh akar tanaman okra, seperti unsur $\mathrm{N}$ yang memiliki peran penting pada awal pertumbuhan tanaman okra. Baiknya kandungan hara $\mathrm{N}$ yang diserap akar tanaman akan memacu laju fotosintesis tanaman okra, sehingga baiknya fotosintesis pada tanaman akan memacu perkembangan batang pada okra.
Pada Tabel 2 menunjukkan bahwa pengaruh utama perlakuan NPK 16:16:16 memberikan pengaruh yang berbeda nyata terhadap tinggi tanaman bawang merah, dimana perlakuan terbaik pada pemberian NPK 16:16:16 dengan dosis 45 g/plot (N3) dengan tinggi tanaman $31,67 \mathrm{~cm}$. Hal ini disebabkan pertumbuhan dan perkembangan awal tanaman bawang merah berlangsung dengan baik, sehingga menghasilkan tinggi tanaman yang baik pula. Tinggi tanaman dipengaruhi oleh serapan hara yang dilakukan oleh akar tanaman terutama hara $\mathrm{N}$ yang diberikan melalui pemupukan NPK 16:16:16.

Pemberian pupuk NPK 16:16:16 dengan dosis 45 g/plot (N3) mampu meningkatkan ketersediaan hara $\mathrm{N}$ yang ada di dalam tanah, sehingga dengan pemberian pupuk NPK 16:16:16 pada tanaman mampu meningkatkan pertumbuhan vegetatif tanaman okra, seperti baiknya pertumbuhan tinggi tanaman.

Pemberian NPK 16:16:16 pada tanaman secara langsung memberikan kebutuhan hara $\mathrm{P}$ pada tanaman dengan baik, unsur ini berperan penting dalam proses metabolism pada tanaman. Fungsi fosfor $(\mathrm{P})$ adalah untuk pembelahan sel, pembentukan albumin, pembentukan bunga, buah dan biji. Selain itu fosfor juga berfungsi untuk mempercepat pematangan buah, memperkuat batang, untuk perkembangan akar, memperbaiki kualitas tanaman, metabolisme karbohidrat (Prasetya, 2014).

Untuk mengetahui pertambahan tinggi tanaman okra dan bawang merah yang ditanam sistem tumpang sari setiap minggunya, dapat dilihat pada Grafik 1 dan Grafik 2 di bawah ini.

Pertumbuhan dan perkembangan tanaman dipengaruhi oleh serapan hara. Hara yang diberikan melalui pemupukan kascing maupun pemberian pupuk NPK 16:16:16 mampu diserap dengan baik oleh akar tanaman. Semakin baik jumlah unsur hara yang dihsilkan oleh akar tanaman, maka akan semakin baik pertumbuhan vegetatif tanaman yang terlihat pada pertambahan tinggi tanaman baik tanaman okra maupun bawah merah. Unsur hara makro berperan penting dalam pertumbuhan vegetatif tanaman, terutama hara $\mathrm{N}$ yang berpengaruh terhadap perkembangan daun pada tanaman, baiknya perkembangan daun memberikan laju fotosintesis yang optimal pada tanaman. 


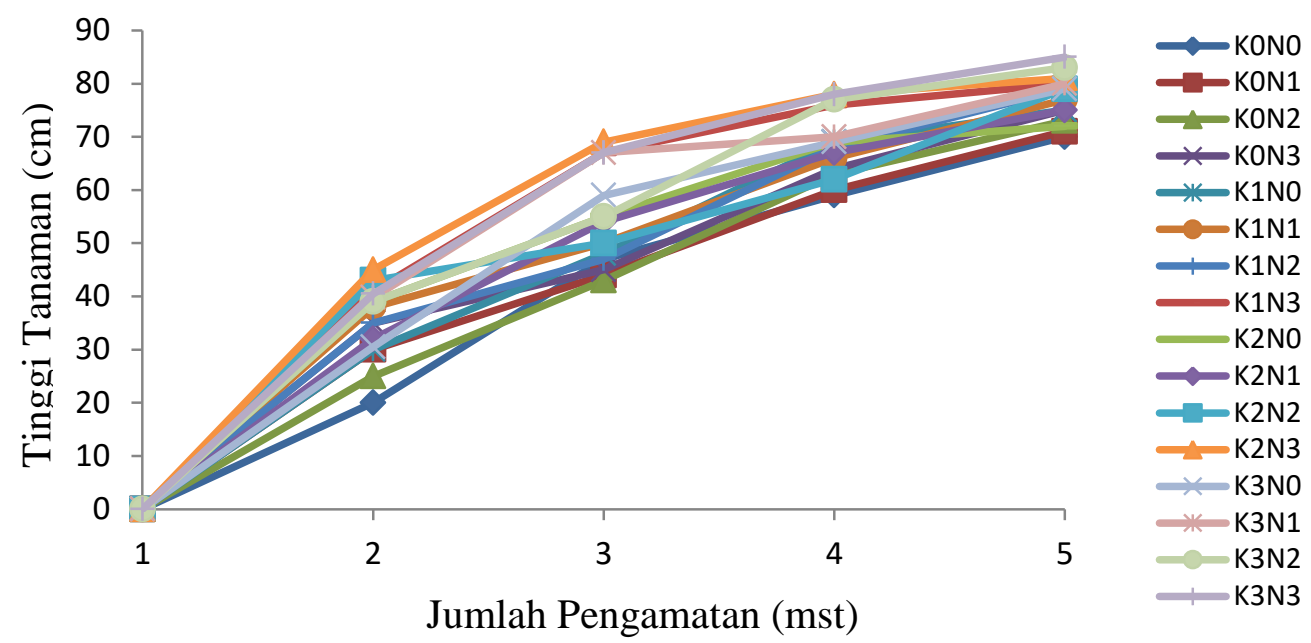

Grafik 1. Pertambahan tinggi tanaman okra $(\mathrm{cm})$

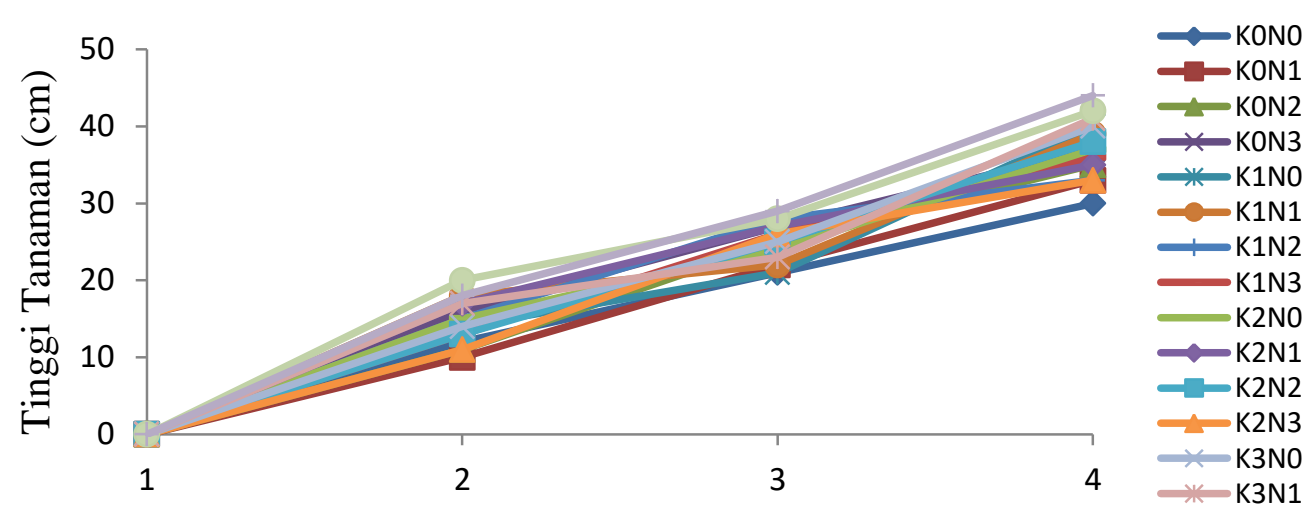

Jumlah Pengamatan (mst)

Grafik 2. Pertambahan tinggi tanaman bawang merah (cm)

\section{Jumlah Buah Per Tanaman (buah)}

Setelah berbagai analisis, pengamatan jumlah buah per okra dan bawang merah yang ditanam dalam tumpang sari menunjukkan bahwa interaksi antara pupuk cacing tanah dan pupuk NPK 16:16:16 tidak memiliki efek nyata. Telah ditunjukkan bahwa jumlah buah memiliki efek utama nyata per tanaman. Pengamatan rata-rata jumlah buah per tanaman selama tumpangsari dapat dilihat pada Tabel 3 dan 4.

Jumlah buah dan jumlah umbi yang dihasilkan tanaman yang ditanam secara tumpang sari juga lebih sedikit dibandingkan dengan tanaman monokultur, tanaman okra menghasilkan jumlah buah per tanaman 41 buah, sedangkan tanaman monokultur 50 buah. Bawang merah menghasilkan jumlah umbi 10,67 buah, sedangkan tanaman monokultur menghasilkan umbi 11,33 buah. Hal ini disebabkan tidak optimalnya kebutuhan hara pada masa pertumbuhan dan perkembangan hara tanaman.

Pada Tabel 3 menunjukkan bahwa pengaruh utama pemberian pupuk kascing memberikan pengaruh yang berbeda nyata terhdap jumlah buah per tanaman okra, dimana perlakuan terbaik pada pemberian dosis pupuk kascing $2250 \mathrm{~g} /$ plot (K3) dengan jumlah buah per tanaman 35,50 buah. Ini disebabkan pemberian perlakuan pada K3 merupakan dosis pemberian yang tepat pada tanaman okra, sehingga tanaman okra menghasilkan jumlah buah yang lebih banyak pada perlakuan tersebut. Kandungan hara $\mathrm{N}, \mathrm{P}$ dan $\mathrm{K}$ pada pupuk kascing yang diberikan dengan dosis pada K3 mampu memenuhi kebutuhan hara yang baik pada tanaman okra.

Pada Tabel 3 menunjukkan bahwa pengaruh utama pemberian pupuk NPK 16:16:16 memberikan pengaruh yang berbeda nyata terhadap jumlah buah per tanaman okra, 
dimana perlakuan terbaik pada dosis NPK 16:16:16 $45 \mathrm{~g} /$ plot (N3) dengan jumlah buah per tanaman okra 35,51 buah. Hal ini dikarenakan pemberian pupuk pada perlakuan N3 mempu meningkatkan ketersediaan unsur hara dalam tanah seperti hara makro N, P dan $\mathrm{K}$, baiknya ketersediaan unsur tersebut, akar tanaman okra mampu menyerap hara dengan optimal dalam pemenuhan hara tanaman pada proses pertumbuhan dan perkembangan buah pada tanaman okra. Baiknya pemenuhan kebutuhan hara ini akan menghasilkan jumlah buah yang banyak pada tanaman okra.

Tabel 3. Rerata jumlah buah per tanaman okra dengan perlakuan pupuk kascing dan dosis pupuk NPK 16:16:16 secara tumpang sari (buah).

\begin{tabular}{lccccc}
\hline \multirow{2}{*}{$\begin{array}{c}\text { Pupuk Kascing } \\
\text { (g/plot) }\end{array}$} & \multicolumn{4}{c}{ Dosis Pupuk NPK 16:16:16 (g/plot) } & Rerata \\
\cline { 2 - 5 } & $\mathrm{N} 0(0)$ & $\mathrm{N} 1(15)$ & $\mathrm{N} 2(30)$ & $\mathrm{N} 3(45)$ & \\
\hline K0 (0) & 28,00 & 31,33 & 31,00 & 35,01 & $31,34 \mathrm{~b}$ \\
K1 (750) & 31,33 & 29,00 & 32,33 & 33,33 & $31,50 \mathrm{~b}$ \\
K2 (1500) & 28,33 & 35,67 & 34,00 & 32,67 & $32,67 \mathrm{ab}$ \\
K3 (2250) & 33,67 & 33,00 & 34,33 & 41,00 & $35,50 \mathrm{a}$ \\
\hline Rerata & $30,33 \mathrm{~b}$ & $32,25 \mathrm{ab}$ & $32,92 \mathrm{ab}$ & $35,51 \mathrm{a}$ & \\
\hline \multicolumn{4}{l}{$\mathrm{KK}=10,69 \%$} & \multicolumn{3}{c}{ BNJ K \& N $=3,88$} & \\
\hline
\end{tabular}

Angka-angka pada kolom dan baris yang diikuti huruf kecil yang sama tidak berbeda nyata menurut uji BNJ pada taraf 5\%.

Tabel 4. Rerata jumlah umbi bawang merah dengan perlakuan pupuk kascing dan dosis pupuk NPK 16:16:16 secara tumpang sari (buah).

\begin{tabular}{|c|c|c|c|c|c|}
\hline \multirow{2}{*}{$\begin{array}{l}\text { Pupuk Kascing } \\
\text { (g/plot) }\end{array}$} & \multicolumn{4}{|c|}{ Dosis Pupuk NPK 16:16:16 (g/plot) } & \multirow[t]{2}{*}{ Rerata } \\
\hline & N0 (0) & N1 (15) & $\mathrm{N} 2(30)$ & N3 (45) & \\
\hline K0 (0) & 6,00 & 7,67 & 8,33 & 8,67 & $7,67 \mathrm{~b}$ \\
\hline K1 (750) & 7,33 & 9,00 & 9,33 & 9,67 & $8,83 \mathrm{a}$ \\
\hline K2 (1500) & 7,33 & 9,33 & 9,67 & 10,33 & $9,17 \mathrm{a}$ \\
\hline K3 (2250) & 8,00 & 9,67 & 10,00 & 10,67 & $9,58 \mathrm{a}$ \\
\hline \multirow[t]{2}{*}{ Rerata } & $7,17 \mathrm{~b}$ & $8,92 \mathrm{a}$ & $9,33 \mathrm{a}$ & $9,83 \mathrm{a}$ & \\
\hline & $\mathrm{KK}=$ & & BNJ & $=0,92$ & \\
\hline
\end{tabular}

Angka-angka pada kolom dan baris yang diikuti huruf kecil yang sama tidak berbeda nyata menurut uji BNJ pada taraf 5\%.

Pada Tabel 4 menunjukkan bahwa pengaruh utama perlakuan pupuk kascing memberikan pengaruh yang berbeda nyata terhadap jumlah umbi tanaman bawang merah, dimana perlakuan terbaik pada perlakuan pupuk kascing dengan dosis $2250 \mathrm{~g} / \mathrm{plot}(\mathrm{K} 3)$ dengan jumlah umbi 9,58 buah. Ini diduga karena pemberian kascing pada media dapat meningkatkan pertumbuhan dan produksi bawang merah dimana pemberian kascing pada tanah dapat memperbaiki sifat fisik, kimia dan biologi tanah seperti menyuburkan tanah, menambah unsur hara, menambah humus, mempengaruhi kehidupan jasad renik yang hidup dalam tanah, selain itu juga dapat meningkatkan kapasitas mengikat air tanah.

Tabel 4 menunjukkan bahwa efek utama dari NPK 16:16:16 memiliki efek yang berbeda secara signifikan pada jumlah umbi bawang merah. Pemrosesan optimal dilakukan dengan dosis $45 \mathrm{~g} /$ plot (N3) dengan jumlah umbi 9,83 unit. Ini karena NPK 16:16:16 aplikasi dapat memenuhi kebutuhan Makro K ketika menanam bawang merah.

\section{Berat Buah Per Tanaman (g)}

Pengamatan berat buah per okra dan bawang merah dengan tumpang sari setelah analisis varians menunjukkan bahwa interaksi antara kompos cacing tanah dan pupuk NPK 16:16:16 tidak memiliki efek nyata, Efek utama utama pada berat masing-masing tanaman. Pengamatan rata-rata berat buah per tanaman dapat dilihat pada Tabel 5 dan 6 .

Penanaman secara tumpang sari okra dan bawang merah, bila dibandingkan dengan tanaman monokultur, lebih baik hasil pada tanaman monokultur. Pada tanaman tumpang sari, okra menghasilkan berat buah per tanaman 793,67, sedangkan pada tanaman monokultur 867,00 g. Pada bawang merah menghasilkan berat umbi kering angin $61,50 \mathrm{~g}$ dan pada tanaman monokultur 76,60 g. Hal ini diduga penanaman secara tumpang sari yang dilakukan memiliki kerapatan yang agak rapat dibandingkan dengan tanaman monokultur, sehingga adanya persaingan penyerapan hara dan sinar matahari dalam proses fotsintesis pada tanaman tumpang sari. Adanya 
persaingan tersebut maka menghambat proses pertumbuhan dan perkembangan umbi pada tanaman dan menghasilkan berat umbi kering bawang merah yang rendah.

Tabel 5. Rerata berat buah per tanaman okra dengan perlakuan pupuk kascing dan dosis pupuk NPK 16:16:16 secara tumpang sari $(\mathrm{g})$.

\begin{tabular}{lccccc}
\hline \multirow{2}{*}{$\begin{array}{c}\text { Pupuk Kascing } \\
\text { g/plot })\end{array}$} & \multicolumn{3}{c}{ Dosis Pupuk NPK 16:16:16 (g/plot) } & Rerata \\
\cline { 2 - 5 } & N0 $(0)$ & N1 (15) & N2 (30) & N3 (45) & \\
\hline K0 (0) & 481,50 & 514,80 & 530,53 & 530,83 & $514,42 \mathrm{~b}$ \\
K1 (750) & 497,60 & 558,07 & 605,57 & 645,80 & $576,76 \mathrm{ab}$ \\
K2 (1500) & 500,73 & 556,47 & 579,13 & 710,27 & $586,65 \mathrm{ab}$ \\
K3 (2250) & 591,50 & 610,63 & 651,87 & 793,67 & $661,92 \mathrm{a}$ \\
\hline Rerata & $517,83 \mathrm{~b}$ & $559,99 \mathrm{ab}$ & $591,78 \mathrm{ab}$ & $670,14 \mathrm{a}$ & \\
\hline \multicolumn{4}{l}{} \\
\hline
\end{tabular}

Angka-angka pada kolom dan baris yang diikuti huruf kecil yang sama tidak berbeda nyata menurut uji BNJ pada taraf 5\%.

Tabel 6. Rerata berat kering angin umbi bawang merah per rumpun tanaman dengan perlakuan pupuk kascing dan dosis pupuk NPK 16:16:16 secara tumpang sari $(\mathrm{g})$.

\begin{tabular}{lccccc}
\hline \multirow{2}{*}{$\begin{array}{c}\text { Pupuk Kascing } \\
\text { (g/plot) }\end{array}$} & \multicolumn{4}{c}{ Dosis Pupuk NPK 16:16:16 (g/plot) } & \multirow{2}{*}{ Rerata } \\
\cline { 2 - 5 } & $\mathrm{N} 0(0)$ & $\mathrm{N} 1(15)$ & $\mathrm{N} 2(30)$ & $\mathrm{N} 3(45)$ & \\
\hline K0 (0) & 28,40 & 35,93 & 36,23 & 37,83 & $34,60 \mathrm{~b}$ \\
K1 (750) & 30,93 & 38,63 & 39,23 & 40,47 & $37,32 \mathrm{~b}$ \\
K2 (1500) & 33,70 & 43,97 & 42,67 & 41,37 & $40,43 \mathrm{~b}$ \\
K3 (2250) & 35,87 & 43,90 & 59,90 & 61,50 & $50,29 \mathrm{a}$ \\
\hline Rerata & $32,23 \mathrm{~b}$ & $40,61 \mathrm{a}$ & $44,51 \mathrm{a}$ & $45,29 \mathrm{a}$ & \\
\hline & $\mathrm{KK}=15,55 \%$ & \multicolumn{4}{c}{ BNJ K \& N = 7,01 } \\
\hline
\end{tabular}

Angka-angka pada kolom dan baris yang diikuti huruf kecil yang sama tidak berbeda nyata menurut uji BNJ pada taraf $5 \%$.

Tabel 5 menunjukkan bahwa efek utama NPK 16:16:16 memiliki efek yang berbeda nyata terhadap berat buah tanaman okra. NPK16: 16: 1645 g / Perlakuan optimal g dengan berat buah 45,29 pada sebidang (N3). Hal ini disebabkan oleh pemenuhan makronutrien seperti $\mathrm{K}$, yang memainkan peran penting dalam pertumbuhan buah dan pengembangan tanaman okra. Adalah baik untuk memenuhi kebutuhan nutrisi-K untuk menyediakan buah yang baik untuk tanaman okra.

Tabel 6 menunjukkan bahwa efek utama kompos cacing tanah memiliki efek yang berbeda nyata terhadap berat kering angin umbi bawang merah. Perlakuan terbaik adalah dosis $2250 \mathrm{~g}$ kompos / cacing tanah (K3) dengan 50,29 g berat kering seperti umbi. Ini karena penggunaan pupuk kascing meningkatkan asupan nutrisi tanaman bawang dengan pengembangan umbi bawang merah yang baik. Pengembangan umbi pada tanaman bawang sangat dipengaruhi oleh jumlah nutrisi yang dihasilkan oleh akar tanaman seperti nutrisi $\mathrm{K}$, di mana ada perang kritis pada pengembangan umbi di bawang merah.

Tabel 6 menunjukkan bahwa efek utama dari dosis pupuk NPK 16:16:16 memiliki efek yang berbeda nyata terhadap berat kering angin umbi bawang merah.
NPK16: 16: $1645 \mathrm{~g} /$ plot (N3) Umbi bawang kering terbaik yang diolah 45, 29 g terhadap berat pupuk. Ini karena menerapkan NPK 16:16:16 dapat memenuhi kebutuhan nutrisi N, $\mathrm{P}$, dan $\mathrm{K}$ dari tanaman bawang. Menurut Rahmah (2013), berat kering tanaman mencerminkan status gizi tanaman dan juga merupakan indikator apakah pertumbuhan dan perkembangan tanaman terkait erat dengan ketersediaan nutrisi.

Hasil penelitian pada tanaman tumpang sari okra dan bawang merah pada berat buah per tanaman okra dikonversi ke hektar mencapai 31,74 ton dan bawang merah 3,075 ton, sedangkan pada tanaman monokultur hasil panen okra mencapai 34,64 ton serta bawang merah 12,25 ton. Pada deksripsi tanaman okra menghasilkan panen per hektarnya 3 ton dan bawang merah 9,9 ton. Hasil tanaman secara tumpang sari lebih rendah dibandingkan dengan tanaman monokultur. Tetapi jika dibandingkan dengan deskripsi tanaman baik hasil panen secara tumpang sari dan monokultur lebih tinggi.

\section{Jumlah Buah Sisa (buah)}

Pengamatan jumlah okra yang tersisa tumpangsari setelah analisis varian menunjukkan bahwa interaksi antara kompos cacing tanah dan pupuk NPK 16:16:16 tidak 
memiliki efek nyata, Efek utama adalah benar pada jumlah buah residu. Pengamatan rata-rata jumlah buah yang tersisa dari tumpangsari okra dapat dilihat pada Tabel 7.

Tabel 7. Rerata jumlah buah sisa tanaman okra dengan perlakuan pupuk kascing dan dosis pupuk NPK 16:16:16 secara tumpang sari (buah).

\begin{tabular}{|c|c|c|c|c|c|}
\hline \multirow{2}{*}{$\begin{array}{l}\text { Pupuk Kascing } \\
\text { (g/plot) }\end{array}$} & \multicolumn{4}{|c|}{ Dosis Pupuk NPK 16:16:16 (g/plot) } & \multirow[t]{2}{*}{ Rerata } \\
\hline & N0 (0) & N1 (15) & $\mathrm{N} 2(30)$ & N3 (45) & \\
\hline K0 (0) & 4,83 & 5,17 & 5,83 & 5,83 & $5,42 \mathrm{~b}$ \\
\hline K1 (750) & 5,83 & 6,17 & 6,17 & 6,83 & $6,25 \mathrm{ab}$ \\
\hline K2 (1500) & 5,83 & 6,17 & 6,50 & 7,00 & $6,38 \mathrm{ab}$ \\
\hline K3 (2250) & 5,83 & 7,00 & 7,33 & 7,33 & $6,88 \mathrm{a}$ \\
\hline \multirow[t]{2}{*}{ Rerata } & $5,58 \mathrm{~b}$ & $6,13 \mathrm{ab}$ & $6,46 \mathrm{ab}$ & $6,75 \mathrm{a}$ & \\
\hline & \multicolumn{2}{|c|}{$\mathrm{KK}=14,79 \%$} & \multicolumn{2}{|c|}{ BNJ K \& N = 1,02 } & \\
\hline
\end{tabular}

Tumpang sari tanaman okra dan bawang merah menghasilkan jumlah buah yang sedikit dibandingkan dengan tanaman yang ditanam secara monokultur, tanaman okra sebagai tanaman utama menghasilkan jumlah buah sisa 7,33 buah, sedangkan tanaman okra yang ditanam secara monokultur menghasilkan jumlah buah sisa 10 buah. Ini disebabkan adanya persaingan baik sinar matahari dan hara sehingga tanaman okra yang ditanam secara tumpang sari menghasilkan fotosintat yang lebih sedikit dibandingkan dengan tanaman okra secara monokultur.

Tabel 7 menunjukkan bahwa efek utama dari penerapan kompos cacing tanah memiliki dampak yang sangat berbeda pada jumlah buah yang tersisa dari tanaman okra. Perlakuan terbaik adalah penerapan kompos cacing tanah 225 pg / kompartemen (K3) dan sisa 6,88 buah. Ini dipercaya bisa memberikan asupan nutrisi selai yang baik. Juga, kesuburan tanah dapat dipertahankan, sehingga akar tanaman berkembang dengan baik dan memberikan pasokan nutrisi yang baik dengan akar tanaman yang baik.
Tabel 7 menunjukkan bahwa efek utama pemberian NPK 16:16:16 memiliki efek yang sangat berbeda pada jumlah buah yang tersisa dari tanaman okra. Perlakuan yang optimal adalah memberikan NPK 16:16:16 45 g / kompartemen (N3) 75 buah. Hal ini dipengaruhi oleh tingkat kemampuan NPK 16:16:16 dalam mempertahankan asupan nutrisi secara terus menerus untuk mempertahankan hasil produksi agar dapat mempertahankan kondisi optimal secara terus menerus. Pada tanaman yang mendapat asupan nutrisi lebih baik, ia masih bisa menghasilkan produksi tinggi secara terus menerus.

\section{Susut Bobot Umbi (\%)}

Pengamatan susut bobot umbi bawang merah yang ditanam secara tumpangsari setelah analisis ragam menunjukkan bahwa interaksi kompos cacing tanah dan pupuk NPK 16:16:16 tidak memiliki efek nyata, tetapi berlaku untuk penurunan berat umbi bawang merah. Efek utama ditunjukkan. Tabel 8 menunjukkan pengamatan rata-rata penurunan berat umbi bawang merah selama tumpangsari.

Tabel 8. Rerata susut bobot umbi tanaman bawang merah dengan perlakuan pupuk kascing dan dosis pupuk NPK 16:16:16 secara tumpang sari (\%).

\begin{tabular}{lccccc}
\hline \multirow{2}{*}{$\begin{array}{c}\text { Pupuk Kascing } \\
\text { (g/plot) }\end{array}$} & \multicolumn{4}{c}{ Dosis Pupuk NPK 16:16:16 (g/plot) } & \multirow{2}{*}{ Rerata } \\
\cline { 2 - 5 } & $\mathrm{N} 0(0)$ & $\mathrm{N} 1(15)$ & $\mathrm{N} 2(30)$ & $\mathrm{N} 3(45)$ & \\
\hline K0 (0) & 21,74 & 19,00 & 15,18 & 13,64 & $17,39 \mathrm{~b}$ \\
K1 (750) & 17,54 & 17,10 & 14,90 & 16,32 & $16,47 \mathrm{~b}$ \\
K2 (1500) & 16,31 & 15,72 & 8,52 & 9,75 & $12,58 \mathrm{a}$ \\
K3 (2250) & 16,84 & 15,19 & 8,20 & 6,57 & $11,70 \mathrm{a}$ \\
\hline Rerata & $18,11 \mathrm{~b}$ & $16,75 \mathrm{~b}$ & $11,70 \mathrm{a}$ & $11,57 \mathrm{a}$ & \\
\hline & $\mathrm{KK}=17,35 \%$ & \multicolumn{3}{c}{ BNJ K \& N $=7,67$} & \\
\hline
\end{tabular}

Angka-angka pada kolom dan baris yang diikuti huruf kecil yang sama tidak berbeda nyata menurut uji BNJ pada taraf 5\%.

Tanaman bawang merah yang ditanam secara tumpang sari denganokra menghasilkan bobot susut umbi lebih tinggi dibandingkan dengan yang ditanam secara monokultur, bawang merah yang ditanam tumpang sari menghasilkan susut bobot umbi $6,57 \%$ sedangkan tanaman bawang secara monokultur $5,45 \%$. Ini disebabkan adanya persaingan 
unsur hara pada proses pertumbuhan dan perkembangan umbi pada tanaman bawang merah, sehingga tanaman bawang merah secara tumpang sari menghasilkan susut bobot umbi yang lebih tinggi.

Tumpangsari menyebabkan persaingan antara tanaman pokok dan tumpang sari. Persaingan dapat berdampak negatif terhadap pertumbuhan dan produksi tanaman. Penempatan sistem tumpangsari dapat meminimalkan kompetisi tanaman ke tanaman atau mendukung satu sama lain untuk pertumbuhan dan produksi dan meningkatkan produktivitas per area lahan. Waktu tanam memainkan peran penting dalam waktu tanam tanaman yang mempengaruhi sumbu, terutama pada tanaman yang sensitif terhadap naungan.

Tabel 8 menunjukkan bahwa efek utama pupuk kompos bihun memiliki efek berbeda yang signifikan terhadap penurunan berat badan tanaman bawang merah, perlakuan terbaik adalah pada dosis $2250 \mathrm{~g} /$ petak (K3) dengan penurunan berat nodul $11,250 \%$. Ini menggunakan pupuk kascing untuk meningkatkan pertumbuhan tanaman pada tanaman bawang, yang memiliki efek yang baik pada fotosintesis tanaman, sehingga merangsang pertumbuhan dan perkembangan umbi tanaman bawang, yang mempengaruhi penyusutan bobot umbi bawang, semua tanaman Ini dapat menghasilkan banyak fotosintesis di seluruh bagian.

Tabel 8 menunjukkan bahwa efek utama dari NPK 16:16:16 memiliki efek yang berbeda secara signifikan pada penurunan berat badan nodular tanaman bawang. Di sini pengobatan terbaik untuk NPK 16:16:16 $45 \mathrm{~g} /$ plot (N3) dengan penurunan berat badan nodular adalah $1157 \%$. Nodules yang dicurigai memproduksi pupuk NPK sebagai hasil dari 16:16:16 dapat meningkatkan kualitas nodul pada tanaman untuk menghasilkan kontraksi nodul yang lebih kecil dibandingkan dengan perawatan lainnya.

\section{KESIMPULAN DAN SARAN}

\section{Kesimpulan}

Berdasarkan hasil penelitian yang telah dilakukan dapat disimpulkan sebagai berikut :

1. Sistem tanam tumpang sari pada tanaman okra dan bawang merah menghasilkan pertumbuhan dan produksi tanaman terbaik pada perlakuan K3N3 tetapi masih lebih kecil dibandingkan dengan tanaman yang ditanam secara monokultur.

2. Interaksi pemberian pupuk kascing dan pupuk NPK 16:16:16 tidak nyata terhadap semua parameter pengamatan.

3. Pengaruh utama dosis pupuk kascing nyata terhadap semua parameter pengamatan. Perlakuan terbaik adalah dosis pupuk kascing $2250 \mathrm{~g} /$ plot (K3).

4. Pengaruh utama dosis NPK 16:16:16 nyata terhadap semua parameter pengamatan. Perlakuan terbaik adalah dosis NPK 16:16:16 $45 \mathrm{~g} /$ plot (N3).

\section{Saran}

Dari hasil penelitian, maka disarankan untuk melakukan penelitian lanjutan dengan sistem tumpang sari tanaman okra dengan berbagai jenis tanaman dan penambahan dosis pupuk kascing ataupun NPK 16:16:16, agar diperoleh produksi yang maksimal.

\section{DAFTAR PUSTAKA}

Anonimus. 2015. Peluang Terbuka Budidaya Okra tersedia pada www.jurnalasia.com/bisnis/peluangterbuka-budidaya-okra. Diakses pada tanggal 22 Juni 2019.

Anonimous. 2017. Data BPS Bawang Merah. https://riau.bps.go.id/. (Diakses pada tanggal 25 desember 2018).

Damanik, M. M. B., B. E. Hasibuan, Fauzi, Sarifuddin, H. Hanum., 2010. Kesuburan Tanah dan Pemupukan.USU. Press. Medan.

Napitupulu, D. Dan L. Winarto. 2009. Pengaruh Pemberian Pupuk N dan K Terhadap Pertumbuhan dan Produksi Bawang Merah, Medan.

Prasetya, M.E. 2014. Pengaruh Pupuk NPK Mutiara dan Pupuk Kandang Sapi Terhadap Pertumbuhan dan Hasil Tanaman Cabai Merah Keriting Varietas Arimbi. Jurnal AGRIFOR. 13 (2): 191-198.

Rahmah, A. 2013. Pertumbuhan dan Produksi Bawang Merah (Allium ascalonicum L.) dengan Pemberian Pupuk Kandang Ayam dan EM4 (Effective. Microorganisme4). Jurnal Online Agroteknologi. Fakultas Pertanian USU, Medan.1 (2) : 4-7.

Sasmita, I., Supriyono, dan S. Nyoto, 2014. Pengaruh Berbagai Varietas Jagung secara Tumpangsari Additive Series 
pada Pertanaman Kacang Tanah terhadap Pertumbuhan dan Hasil. J. Ilmu-ilmu Pertanian. 29 (1): 45-51

Suresha, BA, Allolli, TB, Patil, MG, Desai, BK \& Hussain, SA. 2010. Yield and economics of chilli based intercropping system. Karnataka Journal of Agricultural Sciences. 20 (10): 807-809.

Widyastuti, R. 2009. Pengaruh Pemberian Pupuk Majemuk NPK Phonska dan Pupuk Hayati Petrobiofertil Pada Pertumbuhan dan Hasil Kedelai. Skripsi. Universitas Brawijaya. 